\title{
The Relationship between Teachers' Effectiveness and Management of Classroom Misbehaviours in Secondary Schools
}

\author{
Bonke A. Omoteso, Adeola Semudara \\ Department of Educational Foundations and Counselling, Obafemi Awolowo University, \\ Ile-Ife, Nigeria. \\ Email: baomoteso@yahoo.co.uk \\ Received August $4^{\text {th }}$, 2011; revised September 20 $0^{\text {th }}$ 2011; accepted October $29^{\text {th }}, 2011$.
}

\begin{abstract}
The study investigated the nature of classroom misbehaviours among secondary school students in Ondo State, Nigeria. It also determined the effectiveness of the teachers and the strategies adopted by the teachers to manage classroom misbehaviours. Furthermore, it established the relationship between teachers' effectiveness and management of classroom misbehavior with a view to maintaining discipline in schools. The study adopted descriptive survey design. The population comprised the teachers and school administrators in Ondo State. The sample consisted of 420 teachers and 180 school administrators selected randomly from 10 secondary schools selected by stratified sampling technique using location of schools and ownerships of schools as strata. Two instruments namely "Questionnaire on Management of Classroom Misbehaviour" (QMCM) and "Teacher Effectiveness Scale" (TES) were used to elicit information from the students. QMCM was made up of three sections. Section A consisted of items on socio-demographic variables such as sex, location of schools and ownership of schools. Section B requested the teachers to indicate the types of misbehavior that take place in the classroom and their frequencies of occurrence. Section C comprises strategies used by teachers to manage classroom misbehaviours. TES was the ratings of teachers' effectiveness as done by the school administrators. Results showed that the following misbehaviours occurred frequently in the classrooms: talking while was teaching (75.4\%) and fighting (90.9\%). The strategies adopted by teachers included giving advice (90.5) and referring the students to the school counsellors (88.6\%). The teachers were rated effective in attending classes punctually $(81.3 \%)$ and in communicating clearly with the students (96.0\%). Furthermore, there existed a significant relationship between teachers' effectiveness and management of classroom misbehavior, $r=0.0525$ which is significant at .05 level.
\end{abstract}

Keywords: Teachers’ Effectiveness, Management, Misbehaviour

\section{Introduction}

Classroom misbehavior among students is one issue that both parents and educators agree is a problem. Many people blame the teachers and the school authority. Many others believe that the media including music, television, books and recently the internet have been responsible for classroom misbehaviours. It is a fact that in the past, our secondary schools experienced only few cases of classroom misbehaviour, but in the "computer age" where adolescents are exposed to violent films, wrestling, boxing and other different kinds of exposure, classroom misbehavior increases.

Classroom misbehavior among secondary school students is any activity that interferes with teaching and learning. Activities such as unpreparedness for class, talking in class, fighting, cheating, rudeness to teachers, and so on might disrupt the process of teaching and learning (Slavin, 2001; Hussain, 2005). Misbehaviour is also any activity that hinders the misbehaving students to learn. Misbehaviour can arise because students feel frustrated and bored in schools. Another reason why students misbehave is because they want teachers' attention. A lot of problems which teachers must deal with are minor disruptions in the classroom. In dealing with classroom problems, it is best to correct behaviours by using the simplest intervention. Thus, it is expected that if the teachers takes cognizance of the unruly behavior of the students and applies the appropriate class control method, punishment or sanctions, the students will derive maximum advantage from the classroom learning. However, in order that the teacher may be able to effectively manage his/her classroom, he/she needs to have sufficient and more importantly confidence and develop abilities in classroom management (Cartledge \& Johnson, 1996). Martin, Limfort \& Stephenson, 1999) revealed that most teachers confessed that their inability to deal with misbehavior in their classrooms was as a result of their lack of experience and preparation. By implication, confidence is a prerequisite to effective classroom management (Cartledge \& Johnson, 1996).

The ability of a teacher to effectively manage a classroom depends also on the teacher's mode of training and work experience (Lin \& Gomell, 1998). The Nigerian Certificate of Education (NCE) is the basic qualification for teachers in primary and junior secondary schools in Nigeria. This minimum standard was fashioned out to produce highly qualified and competent teachers in primary and junior secondary schools in Nigeria. (National Policy on Education (NPE), 2004). As indicated in the NPE a would be teacher should undergo at least a three year teacher training programme in the university in order to qualify as senior secondary school teacher. Sadly, many teachers lack the skills required to be effective as teachers, due to poor preparation in the training process. In fact, Little (1999) found that many teachers who completed their teacher education reported not to have received formal training on classroom management. It is therefore not surprising that most teachers find it difficult to handle classroom behavioural problems that students elicit (Cains \& Brown, 1998).

Further, the experience (length of service) of the teacher may also be a potent factor in determining the success that the teacher makes of his or her teaching in the classroom. Perhaps, it may be highly expected that a teacher with a long service in 
the school would have developed level of experience that can make him to be confidence in classroom management (Welsh, 1995). It may thus be expected that a teacher who has spent a long time in teaching activities would likely surpass his counterparts with fewer years in the teaching career. This may suggest that there is a relationship between work experience and ability to effectively manage classroom misbehavior. In the opinions of Gailo \& Little, (2003), teachers develop a range of behaviour management strategies as they spend more time in the classroom and deal with behavioural problems of their students.

A teacher's gender may also affect the effective management of classroom behavioural problems. It is common belief that female teachers are less firm when it comes to management of classroom misbehaviours and may not be able to effectively manage the classroom as their male counterparts. To Savran and Cakirogu (2003) male teachers are more in control of their classrooms because they are autocratic, rigid, impersonal, assertive and more aggressive than female teachers.

There are lots of other factors that influence the classroom misbehavior like peer influence, school size and school climate, poverty and so on. Manifestation of students' misbehaviour can range from mild indiscipline to non-criminal acts committed in the school and juvenile delinquency. While the most common students' behaviour problems involve non-criminal conduct, behaviour problems can appear in children as young as early elementary years. Hence, the worst student behavior problems are often experienced in high school.

The issue of classroom misbehavior calls for concern, In Ondo state it has been taken for granted for a long time consequently contributing considerably to poor and under-achievement of most students in secondary schools. In fact, it hinders the misbehaving students' ability to learn.

\section{Purpose of the Study}

The purpose of this study is to

1) Investigate the nature of classroom misbehavior in secondary schools;

2) Examine the factors (sex, location of school, school ownership) associated with classroom misbehavior in secondary schools;

3) Investigate the strategies that are being used by teachers to manage classroom misbehavior;

4) Determine the teachers effectiveness in managing classroom misbehavior; and

5) Establish the relationship between teachers' effectiveness and their ability to manage classroom misbehavior.

The following question are asked to guide the study

1) What is the nature of classroom misbehaviours among secondary school students?

2) What are the factors associated with classroom misbehavior among the students?

3) What are the strategies adopted by the teachers to manage classroom misbehaviours?

4) How effective are the teachers in managing classroom misbehaviour?

\section{Research Hypotheses}

1) There is no significant sex difference in the management of classroom misbehavious by the teachers.

2) There is no significant influence of school location on the management of classroom misbehaviours by the teachers.

3) There is no significant influence of ownership of school on the management of classroom misbehavior by the teachers

4) There is no significant relationship between teachers' effectiveness and management of classroom misbehaviours by the teachers.

\section{Methods}

\section{Research Design}

The study employed survey research design.

\section{Population and Sample}

The population comprised all teachers and school administrators (Principals, Vice Principals and Heads of Departments) in Ondo State, Nigeria. The sample for the study consisted of 420 teachers and 180 school administrators selected randomly from 10 secondary schools selected by stratified randomly (using location of school and school ownership as strata) from each of the six senatorial districts in the state. Seven teachers and three school administrators were selected from each of the selected sixty secondary schools.

\section{Research Instruments}

Two instruments titled "Questionnaire on Management of Classroom Misbehaviour” (QMCM) and “Teachers' Effectiveness Scale" (TES). The QMCM was adopted from Adeniyi (2007) while the TES was adopted from Omoteso (1998). The QMCM was made up of three sections. Section A was made of socio-demographic variables such as sex, school location and school ownership. Section B requested the teachers to indicate the frequencies of occurrence of the various classroom misbehaviours such as talking while the teacher is teaching, rudeness to teachers, distraction, eating during lesson, sleeping during lesson, chorus answers, chewing gum and leaving classroom without permission. Three points Likert scale was used ranging from "Always", "Frequently", and "Never" which were coded 3 2 , and 1 respectively. Section comprised strategies for managing classroom misbehaviours. The teachers responded to the items on three points Likert scale from "Agreed” (3), or "Disagreed" (2) or "Undecided" (1). The School Administrators also filled this section for the teachers they rated for effectiveness. The TES was the ratings of teachers' effectiveness as done by the School Administrators The items were also rated on four points of "Very Effective" (3) "Effective" (2), and "Not Effective" (1). The instruments were validated by the original users. The test re-test reliability of QMCM as carried out by Adeniyi (2007) yielded a correlation coefficient of 0.86 while that of TES was 0.76 (Omoteso, 2004). The test re-test reliability coefficients of the instruments as carried out by the researchers were 0.79 for QMCM and 0.85 for TES. All these values are significant at .05 level.

\section{Results}

First, answers are provided for the research questions.

Research Question 1: What is the nature of classroom misbehaviours among secondary school students?

In order to answer this question, the information elicited from the teachers on the nature of misbehaviours they experienced in their classrooms was subjected to frequency counts and percentage analysis. The results are presented in Table 1.

Table 1 shows the nature of classroom misbehaviour in sec- 
ondary schools studied. Majority of the respondents $(75.4 \%, \bar{x}$ $=1.51$ ) indicated that students frequently engaged in talking while the teacher is teaching. Other misbehaviours frequently exhibited by secondary school students were fighting during class work $(90.9 \%, \bar{x}=1.81)$, aggression $(72.0 \%, \bar{x}=1.41)$, bullying $(75.3 \%, \bar{x}=1.51)$, rudeness to teachers $(74.2 \%, \bar{x}=$ 1.48), sleeping in class during lesson $(68.7 \%, \bar{x})$, giving chorus answers $(68.9 \%, \bar{x})$ and copying the notes from other student during lesson. Furthermore, $(75.4 \%, \bar{x}=1.51)$ indicated that the students frequently displayed unpreparedness for class work. Boredom was seen as a major kind of misbehavior exhibited by the students by $43.5 \%(\bar{x}=0.57)$ of the respondents. However, many respondents $(76.0 \%, \bar{x}=)$ indicated that the students never got involved in cheating and $82.0 \%(\bar{x}=1.58)$ indicated that the students rarely chewed during lesson and that the students never left the classroom without permission $(73.3 \%, \bar{x}=$ $0.74)$.

Research Question 2: What are the strategies adopted by the teachers to manage classroom misbehaviour?

To answer this question, the responses of the teachers on the strategies adopted by the teachers to manage classroom misbehavior were subjected to percentage analysis. The results are presented in Table 2.

Table 2 indicates the strategies used by secondary teachers in managing classroom misbehavior. Majority of the teachers (90.5\%, $\bar{x}=2.72)$ gave advice to the students who misbehaved. Other strategies used by the teachers were referring the students to the school counsellors $(88.6 \%, \bar{x}=2.66)$, and fixing eyes on the misbehaved student $(88.2 \%, \bar{x}=2.65)$. Furthermore, other strategies identified by the teachers were assigning a portion of land to be cleared by the student who misbehaved $(57.6 \%, \bar{x}=1.73)$, making the student to stand at back of the classroom during lesson $(59.6 \%, \bar{x}=1.79)$, moving the student from his seat to another $(56.7 \%, \bar{x}=1.70)$ and reporting to the school principal or vice principal $(53.5 \%, \bar{x}=$ 1.60) However, 64.6\% ( $\bar{x}=1.29)$ of the teachers disagreed with giving the students who misbehaved strokes of the canes. Other strategies that the teachers disagreed with were reporting the students to their parents $(64.6 \% \bar{x}=1.29)$, sitting near the students during lesson $(70.0 \%, \bar{x}=1.40)$, giving painful punishments $(60.9 \%, \bar{x})$, calling out the student's to insult him (72.7\%, $\bar{x})$, sending the student out of the classroom (51.3\%, $\bar{x}=1.03$ ) and asking the student to close his eyes and raise up his hands.

Research Question 3: How effective are the teachers in managing classroom misbehaviour?

In order to answer this question, the information collected from the teachers from the school Principals, Vice Principals and Heads of Departments was subjected to percentage analysis. The results are presented in Table 3.

Table 3 shows that the teachers were rated effective in attending class punctually by $81.3 \%,(\bar{x}=2.44)$ communicating clearly with the students $(96.9 \%, \bar{x}=0.02)$, attending to students' enquiries $(96.9 \%, \bar{x}=0.01)$, checking students' notes (78.8\%, $\bar{x}=2.06$ ) and giving assignments regularly by $60.0 \%$, $(\bar{x}=1.80)$. They were rated effective in providing feedback to students on assignments by $64.4 \%(\bar{x}=1.93)$, revising class work with students $(68.2 \%, \bar{x}=2.04)$, accessibility to students (90.6\%, $\bar{x}=2.72)$, friendliness with students $(95.1 \% \bar{x}=$ 2.85), and being firm on matters of students' behavior. Furthermore, they were rated very effective in that they were well respected by most students by $84.4 \%, \bar{x}(\bar{x}=2.53)$ writing lesson notes promptly and properly $(58.8 \%, \bar{x}=1.76)$, providing marking scheme for grading $(52.2 \%, \bar{x}=1.59)$ and taking pains to explain difficult exercise to students when necessary $(87.5 \%, \bar{x}=2.63)$.

Research Hypothesis 1: There is no significant sex difference in the management of classroom misbehaviour by the teachers.

To test this hypothesis, the information collected from the teachers on management of classroom misbehaviour of students and their sex was subjected to t-test analysis. The results are presented in Table 4.

Table 1.

Classroom misbehaviours among secondary school students.

\begin{tabular}{llcccccc}
\hline \multirow{2}{*}{ S/N } & Classroom Misbehaviours & \multicolumn{2}{c}{ Always } & \multicolumn{2}{c}{ Frequently } & \multicolumn{3}{c}{ Never } \\
\cline { 3 - 8 } & & $\%$ & $\bar{x}$ & $\%$ & $\bar{x}$ & $\%$ & $\bar{x}$ \\
\hline 1 & Talking while the teacher is teaching & 4.2 & 0.16 & 75.4 & 1.51 & 20.4 & 0.20 \\
2 & Fighting & 2.7 & 0.08 & 90.9 & 1.81 & 6.4 & 0.06 \\
3 & Cheating & 4.2 & 0.12 & 19.1 & 0.38 & 76.0 & 0.76 \\
4 & Aggression & 5.5 & 0.16 & 72.0 & 1.44 & 22.5 & 0.23 \\
5 & Bullying & 10.0 & 0.30 & 75.3 & 1.51 & 14.7 & 0.15 \\
6 & Rudeness to teacher & 12.2 & 0.37 & 74.2 & 1.48 & 3.6 & 0.05 \\
7 & Causing distractions & 19.1 & 0.57 & 70.7 & 1.41 & 10.2 & 0.10 \\
8 & Eating during lesson & 22.0 & 0.66 & 73.8 & 1.48 & 4.2 & 0.04 \\
9 & Sleeping during lesson & 13.8 & 0.41 & 68.7 & 1.37 & 17.5 & 0.18 \\
10 & Boredom & 13.4 & 0.40 & 43.5 & 0.57 & 43.1 & 0.43 \\
11 & Chorus answers & 8.4 & 0.25 & 68.9 & 1.38 & 22.7 & 0.23 \\
12 & Copying notes from other student's note during lesson & 12.4 & 0.37 & 72.7 & 1.45 & 14.9 & 0.15 \\
13 & Unpreparedness for class work & 4.2 & 0.12 & 75.4 & 1.51 & 20.4 & 0.20 \\
14 & Chewing in class & 1.8 & 0.05 & 10.2 & 0.32 & 82.0 & 1.58 \\
15 & Leaving classroom without permission & 2.2 & 0.07 & 24.5 & 0.49 & 73.3 & 0.74 \\
\hline
\end{tabular}


Table 2.

Strategies for managing classroom misbehaviour.

\begin{tabular}{|c|c|c|c|c|c|c|c|}
\hline \multirow{2}{*}{$\mathrm{S} / \mathrm{N}$} & \multirow{2}{*}{ Strategies } & \multicolumn{2}{|c|}{ Agreed } & \multicolumn{2}{|c|}{ Disagreed } & \multicolumn{2}{|c|}{ Undecided } \\
\hline & & $\%$ & $\bar{x}$ & $\%$ & $\bar{x}$ & $\%$ & $\bar{x}$ \\
\hline 1 & Given strokes of cane & 31.8 & 0.95 & 64.6 & 1.29 & 3.6 & 0.04 \\
\hline 2 & Assignment of farm portion to clear & 57.6 & 1.73 & 40.9 & 0.82 & 1.5 & 0.01 \\
\hline 3 & Reporting to parents & 33.8 & 1.01 & 64.6 & 1.29 & 1.6 & 0.02 \\
\hline 4 & Moving student from one seat to another & 56.7 & 1.70 & 42.4 & 0.85 & 0.9 & 0.01 \\
\hline 5 & Reporting to principal or vice principal & 53.5 & 1.60 & 44.7 & 0.89 & $1 / 8$ & 0.02 \\
\hline 6 & $\begin{array}{l}\text { Making the students to stand at the back of the } \\
\text { classroom. }\end{array}$ & 59.6 & 1.79 & 40.4 & 0.81 & - & - \\
\hline 7 & $\begin{array}{l}\text { Teacher sits beside the misbehaved students while the } \\
\text { teaching is going on }\end{array}$ & 30.0 & 0.90 & 70.0 & 1.40 & - & - \\
\hline 8 & Calling out the student's name to insult him & 26.0 & 0.78 & 72.7 & 1.45 & 1.3 & 0.01 \\
\hline 9 & Giving advice to the student & 90.5 & 2.72 & 8.4 & 0.17 & 1.1 & 0.01 \\
\hline 10 & $\begin{array}{l}\text { Giving pain inflicting exercise such as kneeling down, } \\
\text { and frog jump }\end{array}$ & 37.3 & 1.12 & 60.9 & 1.22 & 1.8 & 0.02 \\
\hline 11 & Fixing eyes on the students & 88.2 & 2.65 & 10.0 & 0.19 & 1.8 & 0.02 \\
\hline 12 & Sending the misbehaved student out of the classroom & 48.0 & 1.44 & 51.3 & 1.03 & 0.7 & 0.01 \\
\hline 13 & Asking the student to closes and hands up & 46.4 & 1.39 & 52.7 & 1.05 & 0.9 & 0.01 \\
\hline 14 & Referring the student to school counselor & 88,6 & 2.66 & 8.7 & 0.17 & 2.7 & 0.03 \\
\hline
\end{tabular}

Table 3.

Teachers' effectiveness.

\begin{tabular}{clcccccc}
\hline \multirow{2}{*}{ S/N } & Items & \multicolumn{2}{c}{ Effective } & \multicolumn{2}{c}{ Just Effective } & \multicolumn{2}{c}{ Not Effective } \\
\cline { 3 - 7 } & The teacher & $\%$ & $\bar{x}$ & $\%$ & $\bar{x}$ & $\%$ & $\bar{x}$ \\
\hline 1 & attends class punctually & 81.3 & 2.44 & 15.6 & 0.09 & 3.1 & 0.03 \\
2 & communicates clearly with the students & 96.0 & 2.91 & 5.1 & 0.02 & - & \\
3 & attends to students' enquiries & 96.9 & 2.91 & 3.1 & 0.01 & - & \\
4 & checks students' notes & 78.8 & 2.06 & 35.0 & 0.49 & 6.2 & 0.06 \\
5 & gives assignment regularly & 60.0 & 1.80 & 24.4 & 0.31 & 15.6 & 0.16 \\
6 & provides feedback to students on assignments & 64.4 & 1.93 & 25.6 & 0.51 & 10.0 & 0.10 \\
7 & revises class work with students & 68.2 & 2.04 & 25.6 & 0.51 & 10.0 & 0.10 \\
8 & is accessible to students & 90.6 & 2.72 & 7.5 & 0.15 & 1.9 & 0.02 \\
9 & is friendly with students & 95.1 & 2.85 & 5.0 & 0.10 & - & - \\
10 & is firm on matters of students' behavior & 87.5 & 2.63 & 8.8 & 0.18 & 3.7 & 0.04 \\
11 & well respected by most students & 84.4 & 2.53 & 9.4 & 0.65 & 6.3 & 0.06 \\
12 & writes lesson notes promptly and properly & 58.8 & 1.76 & 26.9 & 0.37 & 14.3 & 0.14 \\
13 & provides marking scheme for grading & 52.2 & 1.59 & 28.1 & 0.56 & 18.7 & 0.19 \\
14 & takes pain to explain difficult exercise to students & 87.5 & 2.63 & 9.4 & 0.19 & 3.1 & 0.03 \\
\hline
\end{tabular}

From Table 4, there are 220 and 200 female teachers respectively who filled this section of the questionnaire correctly. The mean for the male teachers is 53.32 while that of female is 52.51. The standard deviations of the scores are 5.48 and 5.92, the degree of freedom is 418 . The computed $t$ value is 6.495 which is significant at .05 level. Theses results suggest that there is a significant difference in the ways male and female teachers manage classroom misbehaviour in secondary schools in Ondo State.

Research Hypotesis 2: There is no significant influence of school location on the management of classroom misbehaviour by the teachers.

In order to test this hypothesis, the information collected from the teachers on location (urban and rural) of the school and management of classroom misbehaviour was subjected to $t$ test analysis. The results are presented in Table 5 .

From Table 5, 252 teachers were from urban schools while 168 teachers were from rural schools. The mean scores for the two groups are 55.61 and 50.22 respectively. Their standard deviations are 5.78 for teachers from urban schools and 6.08 for teachers from rural schools. The t value is 4.327 which is significant at .05 level. These results show that there is a significant 
influence of school location on the management of classroom misbehaviour by the teachers.

Research Hypothesis 3: There is no significant influence of ownership of school on the management of classroom misbehaviour by the teachers.

To test this hypothesis, the information collected from the teachers on the ownership of schools (private and public) and management of classroom misbehaviour was subjected to t test analysis. The results are presented in Table 6.

Table 6 shows that there were 155 teachers from private schools and 265 from public schools. The mean scores for the two groups are 53.50 and 52.33 respectively. Their standard deviations are 5.48 for teachers from private schools and 6.0 for teachers from public schools. The $t$ value is 2.243 which is not significant at .05 level. The results indicate that there is no significant influence of school ownership on the management of classroom misbehavior by the teachers.

Research Hypothesis 4: There is no significant relationship between teachers' effectiveness and management of classroom misbehaviour by the teachers.

In order to test this hypothesis, the information collected on teachers' effectiveness and management of classroom misbehavior from the school administrators was subjected to Pearson correlation analysis. The results are presented in Table 7 .

From Table 7, 120 School administrators rated teachers on effectiveness scale. The ratings were correlated with the school administrators' scores on management of classroom misbehavior. The correlation coefficient computed for the two measures is .525 which is significant at .05 level. The results suggest that there is a significant relationship between teachers' effectiveness and management of classroom misbehaviour.

\section{Discussion}

The first finding of this study showed that the major classroom misbehaviours prevalent in secondary schools in Ondo state were unpreparedness for class work, talking during lesson, fighting, rudeness to teachers, causing distraction during lessons, sleeping during lessons, giving chorus answers and copying notes during lessons. These misbehaviours are apparent in most of the schools in Ondo state and the reason for this may be as a result of the students wanting to express themselves and the need to exercise their freedom. It may also have to do with the phase of life these students are in, most of them are in their adolescent years. These results corroborate the findings of Slavin (2000); and Hussain (2003). Inattention was identified as one of the types of misbehaviours in the schools studied. The causes of inattention might be as a result of lack of interest of the students in the lesson or the teacher and lack of materials for teaching and learning. Inattention might have also set in if the method of teaching is boring and if time-table is badly arranged. Another form of misbehavior noticed in Ondo state secondary schools was causing distraction in the classroom. Raising issues that are not related to the topic being taught, doing things in excess and over-reacting to issues are some of the ways by which students may cause distractions in schools. The results however, showed that bullying was not rampart in most secondary schools in the state. This result is not in line with the findings of Olweus (1997), Rigby (1997) Donalson (1999) and MacDonald (1999) who found that bullying is the most common form of indiscipline in schools. The implications of these results are that classes will be disrupted and consequently resulting to poor academic performances on the parts of

Table 4.

Sex difference in the management of classroom misbehaviour.

\begin{tabular}{ccccccc}
\hline Sex & $\mathrm{N}$ & $\bar{x}$ & $\mathrm{SD}$ & $\mathrm{Df}$ & $\mathrm{t}$ & $\mathrm{P}$ \\
\hline Male & 220 & 53.32 & 5.84 & 418 & $6.495^{*}$ & $<.05$ \\
Female & 200 & 52.51 & 5.92 & & & \\
\hline
\end{tabular}

*significant at .05 .

Table 5.

Influence of school location on management of classroom misbehaviour.

\begin{tabular}{ccccccc}
\hline Location of School & $\mathrm{N}$ & $\bar{x}$ & $\mathrm{SD}$ & $\mathrm{Df}$ & $\mathrm{t}$ & $\mathrm{P}$ \\
\hline Urban & 252 & 55.61 & 5.78 & 518 & $4.327^{*}$ & $<.05$ \\
Rural & 168 & 50.22 & 6.08 & & & \\
\hline
\end{tabular}

*Significant at 05 .

Table 6.

Influence of school ownership on the management of classroom misbehaviour.

\begin{tabular}{ccccccc}
\hline School Ownership & $\mathrm{N}$ & $\bar{X}$ & $\mathrm{SD}$ & $\mathrm{Df}$ & $\mathrm{t}$ & $\mathrm{P}$ \\
\hline Private & 155 & 53.50 & 5.48 & 418 & 2,243 & $>.05$ \\
Public & 265 & 52.33 & 6.0 & & & \\
\hline
\end{tabular}

Table 7.

Relationship between teachers' effectiveness and management of classroom misbehaviour.

\begin{tabular}{lccc}
\hline \multicolumn{1}{c}{ Correlation } & N & r & P \\
\hline Teachers' Effectiveness & 120 & $0.525^{*}$ & $<.05$ \\
Management of classroom misbehaviour & 120 & & \\
\hline
\end{tabular}

*Significant at .05. 
the students. These misbehaviours might have accounted for poor performances of students in senior secondary school examinations for the past five years in the state specifically and in the country in general.

The study also found the strategies that were used by the teachers to manage classroom misbehaviour in the state. The strategies included giving advice, referring students to the school counsellors, reporting to the school principal, moving students from one sit to another, making any erring student to stand throughout the period, and assigning farm portion to be cleared by the student who misbehaves. These results are in line with the findings of Oladele (2004) who discovered that teachers could manage classroom misbehavior through preaching discipline in the classroom by ensuring orderliness, and power of cooperation among the students. The results also showed that all the strategies adopted by the teachers were capable of controlling classroom misbehaviours among secondary students. The measures such as teachers engaging students in private talk, being friendly with students, use of appropriate method of teaching that ensure good communication and participatory lesson, arranging the class in an orderly manner, teachers attending class regularly, having respect among the students, and taking pains to explain difficult exercises to students when necessary can be helpful in shaping the behaviours of the students. If the teachers are committed to using these strategies, there is bound to be great improvement in the students' behaviours and academic performances. These results are in line with the findings of Carbone (2001).

Furthermore, the results showed that there was a significant difference between the classroom misbehaviour of students from urban and rural secondary schools. This result is expected because in the urban centres, students are exposed to various violent films, horror films, boxing, wrestling and other different kinds of exposure to corruption and indiscipline through the internet thus making classroom misbehavior to be on the increase. The same cannot be said of the students in the rural areas where societal values and culture are paramount and where students guide against soiling their parents names. Parents and teachers therefore must engage their children and students in worthwhile activities. Adequate home works should be given to the students by the teachers and parents must ensure that their children do their home works.

There also existed a significant difference between the classroom misbehaviours of male and female secondary school students. The cases of classroom misbehavior were prevalent among male students than the female ones. This might have been as a result of the nature of the two sexes. In most schools in the state, the cases of reported classroom misbehavior were more among the boys than among the girls. Girls at times exercise some sort of fear for their teachers and parents, while male students are daring especially if their teacher is a female. However, some girls may be unpredictable as some try to compete in all ramifications with their male counterparts thereby resulting into confrontations even in the classroom. These results corroborate the findings of MacDonalds (1999) that affirmed that girls display subtler and complex forms of behavior than boys but these behaviiours may be difficult to detest.

A significant difference was not found between the management of classroom msibehaviours of teachers from privately and publicly owned secondary schools in the state. The reason for this might be because the teacher in both types of school undergo similar training and programmes and are equipped with the same techniques of handling classroom problems. In the state, all teachers are allowed to attend seminars and work- shops organized by the state government on the need to improve educational standard in the state. At these seminars and workshops, teachers are taught how to deal with classroom situations when problems occur and the need to ensure teacherstudent relationship in a progressive way.

In this study a process measure of teachers' effectiveness was used, namely the ratings of the School Administrators (Principals, Vice-Principals and Heads of Departments). A significant relationship was thus found between teachers' effectiveness and their management of classroom misbehaviours. This result is not unexpected because an effective teacher is the one who possesses such characteristics as impartiality, firmness in decision making, possession of adequate knowledge of his subject, of good personality and a role model to the students. The attributes are necessary for teachers to manage classroom situation accordingly and to be able to relate more professionally with students. These results confirm the findings of Rogers (1999) and Crone (2000) who discovered that adoption of democratic approach by the teacher is necessary to enhance student-teacher relationship. Also, students prefer a teacher who is friendly and ready to listen to their complaints. The implication of the finding is that any teacher who possesses these attributes may be adequately equipped to manage students' classroom problems.

\section{Conclusion}

The study concluded that the secondary school students studied were involved in classroom misbehaviours such as fighting, talking while the teachers were teaching, and eating during lessons. Managing the classroom misbehaviours would depend on how effective the teachers are, because this study found a significant positive relationship between teachers' effectiveness and management of classroom misbehavior.

\section{Recommendations}

- Teachers should take time to study their misbehaving students in order to help them adjust.

- Teachers should adopt democratic approach as this enhances student-teacher relationship.

- Teachers should attend seminars organized by the state government on the need to improve the educational standard in the state.

- Parents should make themselves more available and accessible to their adolescent children. This is in a bid to know them better and help them make positive use of their time.

- Parents should monitor what their children watch on the television and the internet.

- The government at the state level should ensure that each school has at least one trained counsellor instead of leaving the teacher to do all the work.

\section{References}

Adeniyi, W. O. (2007). A study of management of the classroom behavioural problems in secondary schools in Osun State. Master's Thesis, Ile-Ife: Obafemi Awolowo University. Unpublished.

Cains, R. A., \& Brown, C. R. (1998). Newly qualified teachers: A comparative analysis of the perceptions held by B.Ed. nad PGDEtrained primary teachers on the level and frequency of stress experienced during the first year of reading. Educational Psychology, 18, 1. doi:10.1080/0144341980180107 
Carbone, E. (2001). Arranging the classroom with an eye (and ear) to students with ADHD. Teaching Exceptional children, 39, 211-228.

Catledge, G., \& Johnson, C. T. (1996). Inclusive classrooms for students with emotional and behavioural disorder: Critical variables. Theory and Practice, 35, 51-57. doi:10.1080/00405849609543701

Crone, F. (2000). The responsible thinking classroom. The Boys in school bulletin, 3, 4-9.

Donaldson, E. L. (1999). A comparative study of educational policies and effective school-based strategies to reduce violence in schools: Canada, Finland and Scotland. In G. Malicky. B. Shapiro, \& K. Mazurek (Eds.), Building foundations for safe and caring schools: Research on distruptive behavior and violence (pp. 199-200). Edmonton: Duval House.

Gailo, R., \& Little, E. (2003) Classroom behavior problems: The relationship between preparedness, classroom experiences and self-efficacy in graduate and student teachers. Australian Journal Educational and Developmental Psychology, 3, 21-24.

Hussain, N. (2003). Helping EFL/ESL students by asking quality questions. The Internet TESL Journal, 9, 10.

Lin, H., \& Gomell, J. (1998). Pre-service teachers' efficacy beliefs in Taiwan. Journal of Research and Development in Education, 32, 17-25.

Little, E. (1999). Conduct disorder: Generalization across settings and implications for home school-based intervention. Unpublished Doctoral Dissertation, Victoria: RMIT University,.

MacDonalds, I. M. (1999). Cross-cultural and cross-national perspec- tives. In G. Malicky, B. Shapiro, \& K. Mazurek (Eds.), Building foundations for safe and caring schools: Research on distruptive behavior and violence (pp. 199-200). Edmonton: Duval House.

Martin, A., Limfort, K., \& Stephenson, J. (1999). How teachers respond to concern about misbehavior in their classroom. Psychology in the Schools, 36, 347-358.

doi:10.1002/(SICI)1520-6807(199907)36:4<347::AID-PITS7>3.0.C O;2-G

National Policy on Education (2004). Federal Government of Nigeria.

Oladele, J. O. (2004). Fundamentals of educational psychology. Handbook for Education students and teachers. Lagos: Johns-Lads Publishers Ltd.

Olweus, D. (1998). Bullying or peer abuse at school. Facts and intervention. Current Directions in Psychological Science, 4, 196-200. doi:10.1111/1467-8721.ep10772640

Omoteso, B. A. (1998). The relationship between teacher verbal behavior and teacher effectiveness in secondary schools in Ife Central Local government Area. Unpublished Masters' Thesis of Obafemi, Ile-Ife: Awolowo University.

Rigby, K. (1997). Attitudes and beliefs about bullying among Ausralian children. Irish Journal of Psychology, 18, 202-209.

Rogers, B. (1999). Links between students behavior problems. Classroom, 20, 20-21.

Slavin, R. E. (2000). Educational psychology: Theory and practice. Boston: Allyn and Bacon. 